\title{
Miranda
}

Revue pluridisciplinaire du monde anglophone /

Multidisciplinary peer-reviewed journal on the English-

speaking world

$12 \mid 2016$

Mapping gender. Old images ; new figures

\section{Exhibition Review: The Fallen Woman}

The Foundling Museum, London, 25 September 2015 -3 January 2016

\section{Catherine Maxwell}

\section{(2penEdition}

\section{Journals}

Electronic version

URL: http://journals.openedition.org/miranda/8130

DOI: $10.4000 /$ miranda.8130

ISSN: 2108-6559

\section{Publisher}

Université Toulouse - Jean Jaurès

Electronic reference

Catherine Maxwell, "Exhibition Review: The Fallen Woman", Miranda [Online], 12 | 2016, Online since 29 February 2016, connection on 16 February 2021. URL: http://journals.openedition.org/miranda/8130 ; DOI: https://doi.org/10.4000/miranda.8130

This text was automatically generated on 16 February 2021

\section{(c) (i) $\odot$

Miranda is licensed under a Creative Commons Attribution-NonCommercial-NoDerivatives 4.0 International License. 


\title{
Exhibition Review: The Fallen Woman
}

The Foundling Museum, London, 25 September 2015 -3 January 2016

\author{
Catherine Maxwell
}

1 The Foundling Museum's recent small exhibition 'The Fallen Woman' forms a salutary contrast with the considerably larger show 'Splendour and Misery: Pictures of Prostitution, 1850-1910' at the Musée d'Orsay, Paris (22 September 2015-17 January 2016). The Paris show, dedicated to the depiction of the 'realities and fantasies' of female prostitution-male prostitution, a thriving concern in this era, being singularly absent-lent heavily on the 'fantasies', serving up the masculine objectification of women with a good deal of erotic titillation. The London show, a much more sombre affair, specifically reflected its location, this being a museum devoted to the history of the Foundling Hospital which dates from 1739. In the eighteenth and nineteenth centuries, it was to this Hospital that unmarried mothers in straitened circumstances brought the babies for whom they were unable to care.

2 During this period when women's sexuality was rigorously controlled by social and moral conventions, the term 'fallen woman' could signify 'prostitute' but more generally designated any woman deemed to have lost her reputation through having had sexual relations outside of marriage. This label could be applied even if the woman had 'lost her virtue' by means of rape, sexual abuse, or violence. This was the case with many of the women applying to leave their babies at the Hospital. Others had been lured into sexual relations by the promise of love and marriage and then subsequently abandoned. Babies were not automatically accepted by the Hospital and women applying to leave their children had to satisfy the Governors that they had not knowingly chosen to be mistresses nor had benefited by financial or material gain. As part of the petition process applicants had to provide statements of their stories to the Hospital authorities who would judge each case on its merits.

3 At the heart of this exhibition, which focuses on the Victorian fallen woman, were representative archival statements by the female applicants, which made for grim reading as they bore witness to the above-mentioned fact that many mothers were the victims of sexual exploitation and abuse. Although these statements, mainly dictated to Hospital staff, were mediated by the transcription process and the women's awareness 
that their confessions had to conform to certain behavioural expectations of respectability, guilt, and repentance, they do go some way to giving us insight into individuals' painful histories. The transcripts were supplemented by paintings and illustrations, some by well-known Victorian artists such as D. G. Rossetti, G. F. Watts, and George Cruikshank, which depicted in different ways the dangers of being a vulnerable young woman in the city and the stark choices available to fallen women. The exhibition also featured a haunting sound installation-a collage of whispered phrases from the applicants' transcripts-in an attempt to give 'voices' to these marginalised and forgotten women.

The paintings displayed in the exhibition were mostly typical of the Victorian narrative genre, vividly suggesting an identifiable storyline and moral framework, and soliciting, albeit in often sentimental or melodramatic ways, sympathy for the female subjects depicted. Robert Dowling's Breakfasting Out (1859) pictures a predatory gentleman eyeing a young milliner's assistant taking her breakfast at a coffee stall; Richard Redgrave's The Outcast (1851) portrays an outraged father showing his fallen daughter the door to the consternation of the rest of her more caring family. D. R. Rossetti's The Gate of Memory (1864) illustrates the seemingly unbridgeable gap between the 'pure' and the 'impure' as the tainted fallen woman nostalgically views happy young girls at play in the street. In Frederick Walker's The Lost Path (1863), a mother carrying a shawlwrapped baby through the snow provokes comparisons with the snow-bound final footsteps of friendless unmarried mothers in novels such as George Eliot's Silas Marner (1861) and Thomas Hardy's Far From the Madding Crowd (1874). In Frank Holl's The Foundling (1874), a policeman cradles a newly discovered abandoned child in his arms while its wildly dishevelled streetwalker mother, compelled to silence, looks on despairingly. Henry Nelson O'Neil's painting A Mother Depositing her Child at the Foundling Hospital in Paris (1855) is a reminder that such harsh decisions were faced by women regardless of nationality (and indeed still are in some parts of the world.) A woman artist, Emma Brownlow, the daughter of one of the Secretaries of the Hospital, provides a small ray of sunshine in The Foundling Restored to Its Mother (1858). Her painting tells us that, very occasionally, women who had prospered did return to claim their children.

This exhibition was curated by the art historian Lynda Nead, herself the author of a respected study on Victorian women's sexuality-Myths of Sexuality: Representations of Women in Victorian Britain (Oxford: Blackwell, 1998). Interestingly, although the press response reproduced some of the most famous images - G. F. Watts's Found Drowned (1858-60) or the destitute suicide who throws herself from a bridge in George Cruikshank's 1858 illustration - reviews concentrated overwhelmingly on the details of the transcripts, with journalists appalled by the depressing testimonies of abuse and exploitation and the moral double standard, for there is, of course, no corresponding Victorian figure of the 'fallen man'. Readers who would like to explore the exhibition in more detail can download pdfs of the informative Exhibition Guide and copies of the women's transcripts from the Foundling Museum website. Both of these documents would be extremely useful in teaching students about the harsh realities of being a 'fallen woman' and unmarried mother in Victorian London. 
INDEX

Keywords: fallen woman, prostitution, morality, Victorian period, sexuality, violence Mots-clés: femme perdue, prostitution, morale, période victorienne, sexualité, violence Subjects: British painting

\section{AUTHORS}

\section{CATHERINE MAXWELL}

Professor of Victorian Literature Queen Mary, University of London c.h.maxwell@qmul.ac.uk 